\title{
Late Paleozoic to Recent Magmatic Evolution of Northern Patagonia
}

by Carlos W. Rapela and Suzanne M. Kay

The geologic evolution of northern Patagonia is dominated by a series of complex magmatic episodes that began in the Paleozoic and continue today. An understanding is just beginning to emerge of how these magmatic events are related to the rate and obliqueness of convergence, to the dip of contemporaneous subduction regimes, to the collision of microcontinents, and to the resulting extensionalcompressional regime. This paper reviews the magmatic belts between $38^{8}$ and $44^{\circ} \mathrm{S}$, briefly summarizes their chemistry and speculates on their tectonic setting.

\section{A Magmatic Record of Gondwana and Andean Evolution}

South of the Rio Colorado $\left(38^{\circ} \mathrm{S}\right)$ in that part of Argentina known as Patagonia, the characteristic geomorphology is controlled by mid-Jurassic rhyolites and by Andean (Creta- ceous to Recent) magmatic rocks, which are essentially absent north of the Rio Colorado. However, Jurassic to Recent igneous and sedimentary sequences represent only the latest events in the complex geological history of Patagonia. Paleozoic geological features also change abruptly across the Rio Colorado (cf. Turner and Baldis, 1979), suggesting that the Paleozoic evolution of Patagonia was also somewhat independent from the rest of the continent. Ramos (1984b) interpreted these differences as the result of a possible collision between a Patagonian microcontinent and the Gondwana plate during the latest Paleozoic.

The pre-Andean magmatic rocks of northern Patagonia are characterized by voluminous silicic plutonic and voleanic suites of late Paleozoic to Jurassic age (Fig. 1), which are

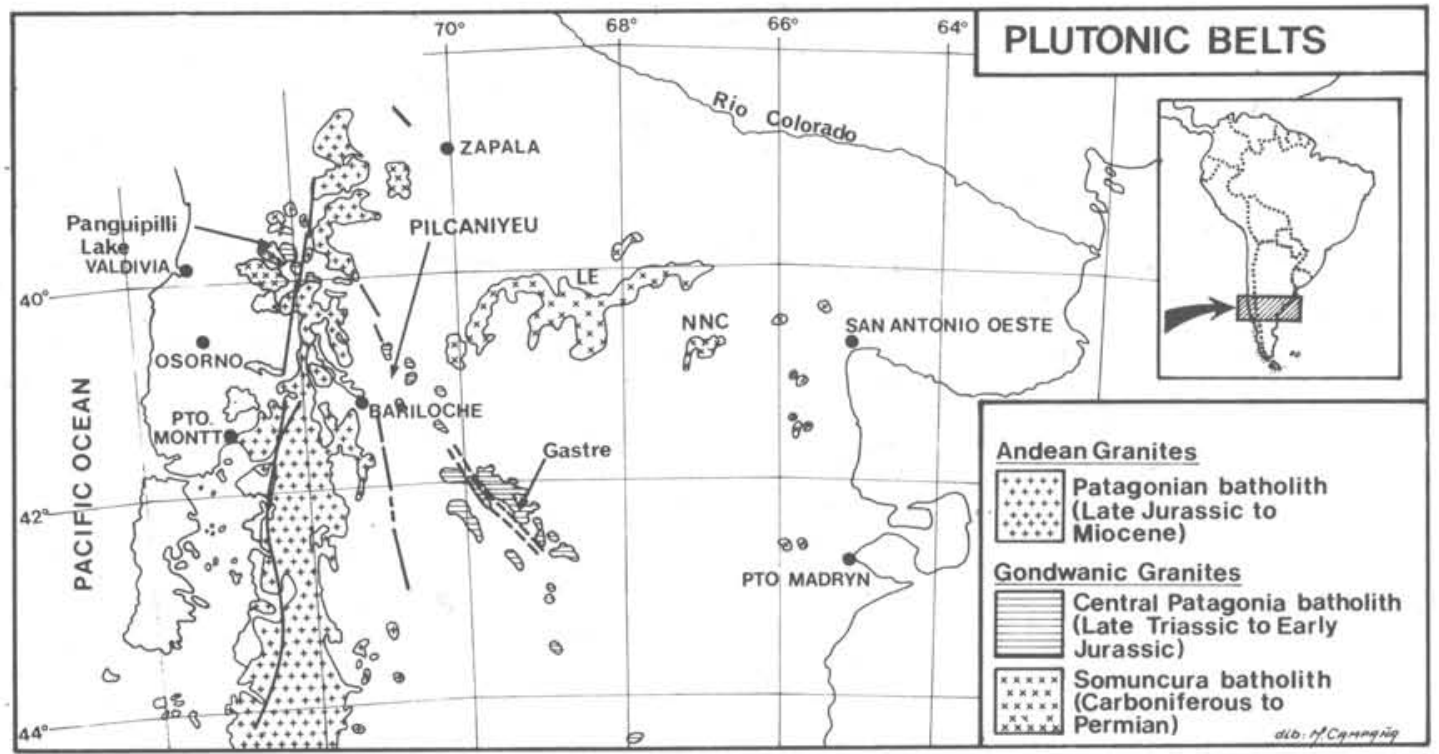

Figure 1: Major magmatic units of northern Patagonia. LE: La Esperanza, LC: Lihuel Calel Plateau, NNC: Nihuel NiyeuCamico.

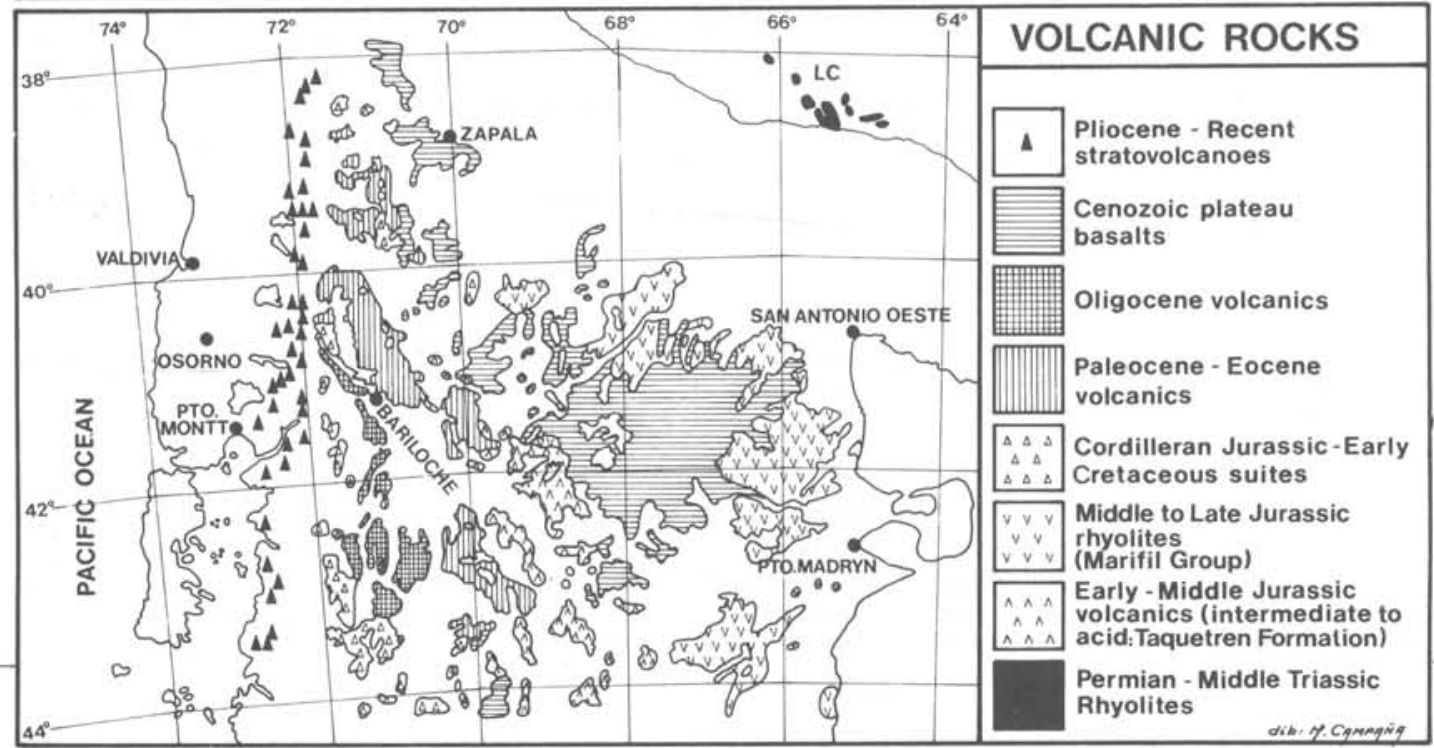


part of the Gondwana magmatic eycle of Patagonia (Llambias et al., in Ramos, 1984a). The Jurassic silicic voleanics, which cover much of Patagonia, constitute one of the largest rhyolitic provinces in the world; they were erupted just prior to the breakup of Gondwanaland (Dalziel et al., 1987; Uliana and Biddle, 1987). Post-Gondwana magmaties include the Andean Cordilleran plutonic and volcanic series, which are related to the subduction of the Nazca plate and its Pacific forerunners. To the east, in the backare and eratonic areas south of $38^{\circ} 30^{\prime} \mathrm{S}$, is the Patagonian plateau basaltic series of Cenozoic age (Fig. 1). The Andean Cordilleran volcanics and the Patagonian plateau series together define the Patagonian Volcanic province (Rapela et al., in Ramos, 1984a; Rapela and Llambias, 1985).

\section{Plutonic Belts of Northern Patagonia}

All of the Gondwana and some of the Andean plutonic rocks intrude a pre-Carboniferous basement composed of schists, gneisses and syn-kinematic granitoids (Cushamen and Mamil Choique formations) whose exact age is still uncertain. Scattered $\mathrm{K}-\mathrm{Ar}$ and model $\mathrm{Rb}-\mathrm{Sr}$ ages indicate middle to late Paleozoic ages, whereas whole-rock $\mathrm{Rb}-\mathrm{Sr}$ isochrons of metamorphic rocks from the northwestern sector suggest Precambrian ages (Linares et al., 1988). In some regions, Andean granites are emplaced into Late Jurassic-Early Cretaceous Cordilleran volcanics.

To the north of the Rio Colorado, the Gondwana plutonic belts are parallel to the modern Andean chain, but to the south of $39^{\circ} \mathrm{S}$ discontinuous outerops of the Gondwana magmatic belts diverge significantly southeastwards (Fig. 2). In the transition area near $39^{\circ} \mathrm{S}$, granitoid ages range from late Paleozoic to Tertiary (Munizaga et al., in press; Rapela et al., 1987). South of the Rio Colorado, two main Gondwana batholiths are recognized and are here referred to as the Somuncura batholith, which is primarily of Carboniferous age, and the Central Patagonia batholith mainly of Early Jurassic age (Fig. 1). and Caminos, in ISGAM, 1987), where the lithology, sequence of intrusion and chemical evolution of the magmatic rocks are very similar. The two main superunits (see Cobbing and Pitcher, 1972), the La Esperanza and the Dos Lomas, were defined in the La Esperanza region to describe an older plutonic and a younger volcanic-plutonic complex, respectively (Rapela and Caminos, ibid).

The La Esperanza superunit is characterized by hornblende-biotite granitoids (tonalite, granodiorite and granite facies with microdioritic enclaves) with $\mathrm{SiO}_{2}$ contents of $61-71 \%$. These granitoids are intruded by biotite granites, some with $\mathrm{K}$-feldspar megacrysts. The evolution of the superunit culminated with the intrusion of microdioritic and lamprophyric (52-60\% $\left.\mathrm{SiO}_{2}\right)$ dikes. The Dos Lomas superunit began with overlying andesitic lavas and dacitic and rhyolitic ignimbrites and culminated with the intrusion of high-silica leucogranites and biotite granites.

$\mathrm{Rb}-\mathrm{Sr}$ whole-rock isochrons on the oldest and youngest granitoid units in both the La Esperanza and Nahuel NiyeuComico areas are remarkably similar, indicating that the main granitic bodies in these regions were emplaced during the Carboniferous between 326 and $317 \mathrm{Ma}$ ago (Llambias et al., 1985; Caminos and Parica, 1985). K-Ar ages of granitoids and acid volcanics from neighboring sectors of the Somuncura batholith (Llambias et al., in Ramos, 1984a) suggest that the latest activity of the batholith was Permian.

\section{The Central Patagonia Batholith}

The Central Patagonia batholith is defined by discontinuous outcrops that extend southeastwards from Panguipulli Lake in Chile, where an age determination of $196 \pm 20 \mathrm{Ma}$ was made by Munizaga and others (in press), to the Pilcaniyeu $(195 \pm 5 \mathrm{Ma}$ - Alonso, 1987) and Gastre (208 $\pm 1 \mathrm{Ma}$ - Rapela et al., 1988; Harrison and co-workers, personal communication) areas in Argentina (Fig. 2), all ages quoted here being $\mathrm{Rb}-\mathrm{Sr}$ whole rock determinations. South of $43^{\circ} \mathrm{S}$, the batholith continues as a string of isolated outcrops, and beyond the Golfo de San Jorge basin, $\mathrm{Rb}-\mathrm{Sr}$ whole rock ages of 196-191 Ma have been reported on plutonic rocks (Stipanicic et al., 1971), suggesting that the Central Patagonia batholith extends as far as the Atlantic Ocean in the region of the Deseado massif $\left(48^{\circ} \mathrm{S}\right.$, see Fig. 2$)$.

The overall composition of the batholith is still poorly known, but from a detailed study of the Gastre area (Rapela et al., in press) two main suites can be distinguished. The older is composed of foliated hornblende-biotite granitoids, which are mainly high-SiO 2 granodiorites. This early suite is intruded by the even more silicic Lipetren suite composed of biotite granites, hornblende granites, and leucocratic granites that commonly have protoclastic textures. Leucocratic twomica granites have been also described in the Lipetren suite in the Pilcaniyeu area (Alonso, 1987). The Lipetren suite is best exposed in the eastern and central sectors of the batholith where it outcrops as

Figure 2: Distribution and possible tectonic setting of late Paleozoic to Mesozoic magmatic rocks of Argentina and Chile. G: Golfo de San Jorge, D: Deseado Massif.

\section{The Somuncura Batholith}

Detailed field, petrological and geochemical studies have been carried out in two regions of the Somuncura batholith: the La Esperanza (Llambias and Rapela, 1984; Rapela and Llambias, 1985) and the Nahuel Niyeu-Comico areas (Rapela small and intermediate size plutons with sharp country rock contacts.

\section{The Andean Patagonia Batholith}

Since Late Jurassic times, the main locus of magmatic activity has been within and subparallel to the modern Andean Cordillera. The plutonic component of this activity is represented by the Andean Patagonia batholith (Fig. 1), which ranges in age from 160 to $8 \mathrm{Ma}$. The spatial distri- 


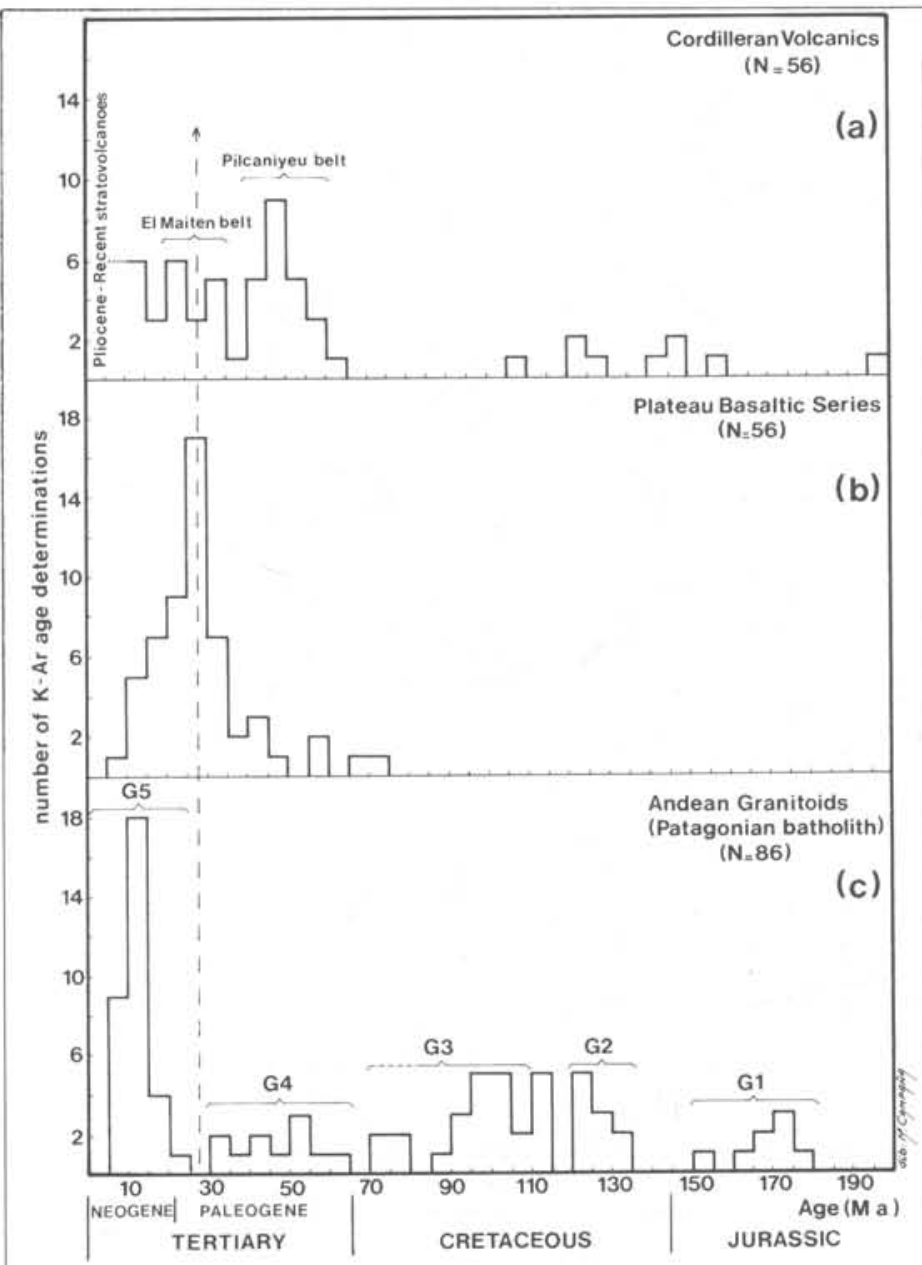

\section{Gondwana Volcanies}

Intermediate to acid volcanics and shallow-level leucocratic granites mark the culmination of the evolution of the Somuncura batholith (Rapela and Caminos, in ISGAM, 1987). The volcanics are equivalent in age to the Choiyoi unit (Fig. 2b), an extensive complex of latest Paleozoic to early Triassic silicic volcanic rocks and related plutons, that outcrops primarily in the eastern and central part of the main Andean Cordillera (the Cordillera Frontal) as far north as $28^{\circ} \mathrm{S}$ (Rapela and Llambias, 1985). Just north of the Rio Colorado, plateau rhyolites and leucogranites equivalent to the Choiyoi complex range in age from 270 to $210 \mathrm{Ma}$ (Linares et al., 1980). The bulk of these rhyolites occur in a region known as the Lihuel Calel plateau (on Fig. 1). A $\mathrm{Rb}-\mathrm{Sr}$ whole rock isochron of $238 \pm 5 \mathrm{Ma}$ (Linares et al., ibid) shows that the Lihuel Calel flows erupted before the emplacement of the Central Patagonia batholith.

A major period of dominantly rhyolitic volcanism began in the latest Triassic and reached its peak during the Middle Jurassic in eastern and central Patagonia (the Marifil Group of Fig. 2b). These rhyolites are equivalent to the extensive silicic volcanies of the Chon-Aike series that cover much of east-central and southern Patagonia (Fig. 2a and Gust et al., 1985). K-Ar ages reviewed by Cortés (1981) indicate that the Chon Aike voleanic rocks erupted from about 200 to 150 $\mathrm{Ma}$ ago, with a peak in the activity around 165 to $155 \mathrm{Ma}$ (Gust et al., ibid). Some of these volcanic rocks are associated in time and space with a series of NNW-trending grabens (Uliana et al., 1985). In the Andean Cordilleran sector, dacitic to rhyolitic rocks about $200 \mathrm{Ma}$ old occur at $39^{\circ} 30^{\prime} \mathrm{S}$ (Rapela et al., 1983).

\section{Andean Volcanism}

The well-documented early Andean Cordilleran voleanics first appeared in Late Jurassic to Early Cretaceous times (155-120 Ma). They comprise the Lago La Plata Formation, the Divisadero Group, the Montes de Oca Formation and their equivalents (Ramos et al., 1982; González Diaz and Lizuain, in Ramos, 1984a). In central Patagonia, a series of basic to acid Jurassic volcanies (the Taquetren Formation) follows the axis of the Central Patagonia batholith, defining a coherent voleanic arc association (Fig. 1). Andesitic rocks of this suite are interlayered with marine Liassic sediments, which contain Early Jurassic ammonites (Musacehio, 1981).

Several major periods of Cenozoic volcanic activity have been described just east of the modern Andean Cordillera (Rapela et al., 1988), with the oldest extending from the Paleocene to the Oligocene (Figs. 1, 3 and 5). Regionally, these older volcanic rocks define two broad belts with Paleocene to Eocene volcanism, principally in the Pilcaniyeu belt to the east, and Oligocene volcanism mainly in the El Maiten belt to the west. Temporal variations, determined by superposition in selected cross-sections, indicate that the early Tertiary episodes began with silicic associations (ignimbritic, plinian and obsidian rhyolitic facies) and ended with intermediate lava flows (stratovolcanoes and monogenetic cones).

During the Oligocene, widespread thick tuffaceous sequences and related thin sheets of ignimbrites accumulated in both the developing pull-apart Nirihuau Basin (Dalla Salda and Franzese, 1987) and the Chilean Longitudinal Depression (Fig. 5). This episode was followed by a period of relative volcanic quiescence in the Late Oligocene and Early Miocene that culminated with compressive deformation of the are and the sedimentary basins (such as the Nirihuau), resulting in the thrusting of older Tertiary voleanic sequences over the basin (Ramos and Cortéz, in Ramos, 1984a).

Major voleanic activity started again in the Middle Miocene with the eruption of silicic ignimbrites of the Collon Cura Formation around $15 \mathrm{Ma}$ ago (Marshall et al., 1977). During 


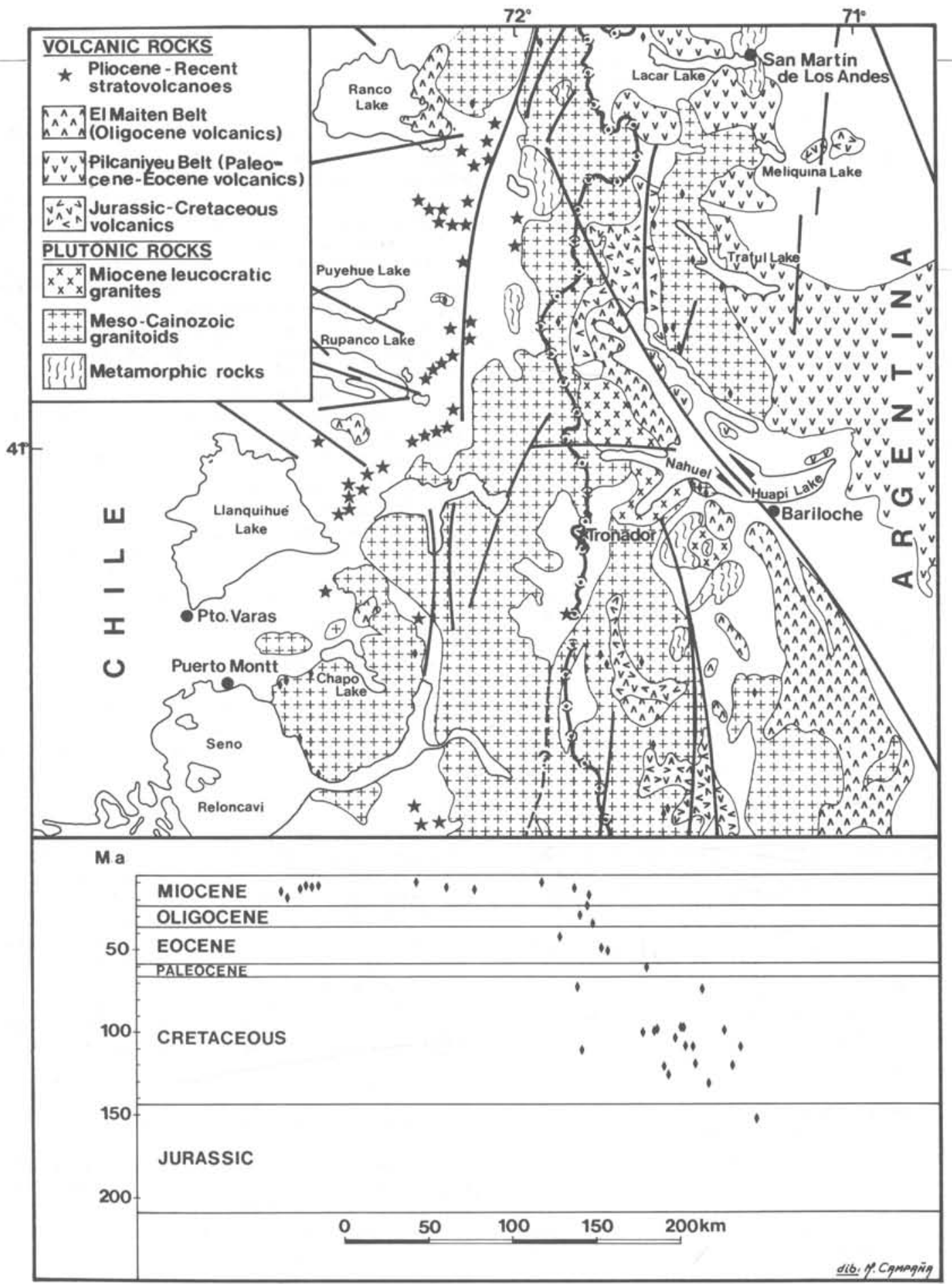

Figure 4: Variation of $K-A r$ ages across the northern sector of the Andean Patagonia batholith. The locations of dated samples are shown by solid diamonds directly above their position on the graph below. See Figure 2 for data sources.

the Pliocene-Pleistocene, volcanism again reached a maximum as large stratovolcanoes, composed mainly of basalts and andesites, were built along the North Patagonian Cordillera (Figs, 1 and 5).

The Plateau Basalt Series (Fig. 1) consists of a sequence of olivine basalts and alkalic complexes located in the back-are and cratonic areas to the east of the Andean orogen. Radiometric ages between $40^{\circ}$ and $43^{\circ} \mathrm{S}$ indicate a protracted period of volcanic activity, ranging from Late Cretaceous to Late Pliocene, with a peak in activity about 30 to $20 \mathrm{Ma}$ ago (Corbella, in Ramos, 1984a). Middle to Late Miocene

activity is apparently absent in this region, and Pliocene volcanism is concentrated in the western part of the plateau (Coira et al., 1985). A similar range of ages for plateau volcanism has been reported to the south, but the peak periods are different (Ramos et al., 1982). Some of the eruptions in the eastern Meseta de Somuncura (Fig. 2) are related to NNW megafractures and grabens (Corbella, 1975), but most are not obviously related to any fault system.

Geochemical Features of Patagonian Igneous Rocks

The plutonic rocks of the Gondwana batholiths all plot in the calc-alkaline field on an AFM diagram (Fig. 6), but different superunits and units within superunits show distinct trends. For example, in the Somuncura batholith the magmatic complexes are composed of several progressively more acidic magmatic pulses that culminate with leucocratic alkali-like plutons emplaced at epizonal levels. These distinct pulses have been interpreted as periodic inputs of 


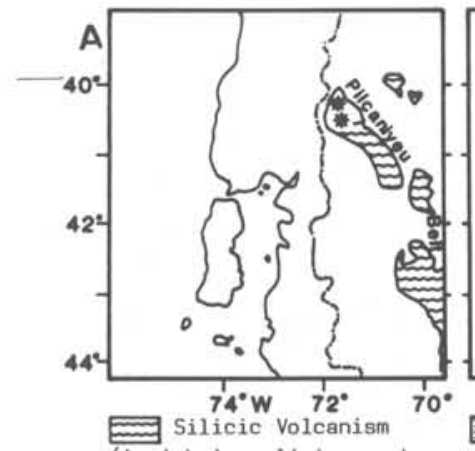

(ignimbric, plinian, subvolcanic and obsidian facies)

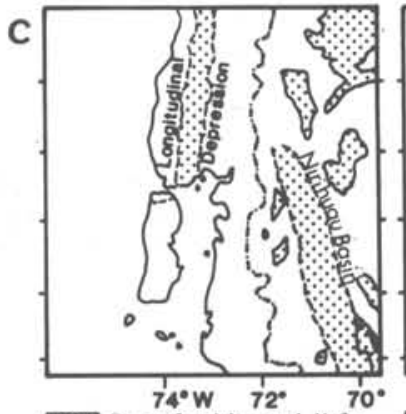

$\because 3$ Pyroclastic and Vol-

caniclastic facies - Sheet

ignimbrites

Figure 5: Generalized paleogeographic reconstruction of the Cenozoic Cordilleran Series. A: Paleocene-Eocene, B: Oligocene, C: Miocene, D: PlioceneRecent. After Rapela and others (1988).

basic magmas in a fractionating magma chamber (Rapela and Llambias, 1985). Variations can also be selected for the superunits in the Gastre area of the Central Patagonia batholith and for individual plutonic episodes in the Andean Patagonia batholith.

Although the Patagonian batholiths all show calc-alkaline affinities (Fig. 6), the Gondwana batholiths exhibit several important chemical differences from the typical I-type Cordilleran suites in the Andean Patagonia batholith. The first is that true granitic compositions are more abundant in the Gondwana batholiths, and gabbros are virtually absent. In contrast, the Andean Patagonia batholith consists principally of tonalites, quartz diorites and granodiorites. Second, the Gondwana granitoids are more enriched in large ion lithophile (LIL) elements such as alkalies, $\mathrm{Rb}$ and $\mathrm{Ba}$, when compared to Andean rocks with similar major element compositions. The latest units of the Somuncura batholith, have alkalic-like signatures. Third, initial $\mathrm{Sr}$ isotope ratios of the Gondwana granites and acid voleanics are relatively high (0.7053-0.7079, Llambias et al., 1985; Caminos and Parica, 1985), suggesting that a crustal component is present in these magmas. In the southern Andean Patagonia batholith, initial $\mathrm{Sr}$ ratios of 0.7074 to 0.7036 decrease with age $(130$ to $46 \mathrm{Ma})$, indicating a progressive decrease in crustal involvement during evolution of the batholith (Weaver et al., in press).

As for the volcanic belts, the Gondwana volcanics of Carboniferous-Permian age and the Jurassic Chon Aike (eastern rhyolitic rocks) are generally richer in $\mathrm{Si}$ and $\mathrm{K}$ than their Andean counterparts (Fig. 7). Jurassic volcanic rocks of Central Patagonia (the Taquetren Formation, see Fig. 1) show a larger compositional range and generally follow a high-K calc-alkaline trend. In the Gastre area, this volcanic succession has been related to a Jurassic magmatic are (Page and Page, 1987).

In northern Patagonia $\mathrm{K}_{2} \mathrm{O}$ generally decreases for a given $\mathrm{SiO}_{2}$ content with diminishing age and decreases with proximity to the western margin of the continent (compare
Figs. 1 and 7). As for the Cenozoic voleanics, $\mathrm{K}_{2} \mathrm{O}$ decreases southward for a given silica content in the Cordilleran volcanics, regardless of age (Hickey et al., in Harmon and Barreiro, 1984; Rapela et al., 1988).

Trace element data for the Cenozoic arc and back-are volcanic rocks show a number of interesting features that help to elucidate their origin and tectonic environment. These features are summarized in Figure 8 in a plot of $\mathrm{Ba} / \mathrm{Nb}$ versus $\mathrm{La} / \mathrm{Nb}$; ratios that are higher in arc volcanic rocks than, in ocean island basalts and mid-ocean ridge rocks. As expected, these ratios are relatively high in Pliocene to Recent arc rocks of the main Andean chain and relatively low in volcanic rocks from the extra-Andean plateau. Interestingly, almost all the volcanic rocks from the Paleocene to Oligocene Pilcaniyeu and El Maiten belts plot in a region intermediate between the arc voleanics and the ocean island basalts (OIB).

These data suggest either that the Tertiary volcanic rocks were erupted in a back-arc setting or that their source area was significantly different to that of the modern Andean arc at these latitudes. Furthermore, for a given $\mathrm{SiO}_{2}$ content, trace element abundances are lowest in volcanic rocks of the Oligocene El Maiten Belt, indicating higher degrees of partial melting of the source during this period.

\section{Cenozoic Magmatism and Subduction Geometry}

A notable coincidence is that the peak of activity in the Plateau Basalt Series of the back-arc and cratonic areas east of the Andean orogen between $39^{\circ}$ and $43^{\circ} \mathrm{S}$ was coeval with the breakup of the Farallon plate and the formation of the Nazca plate about 27-25 Ma ago (Cande and Leslie, 1986). This activity in the plateau is also contemporaneous with an increase in the normal component of convergence from about $4 \mathrm{~cm} /$ year around $25 \mathrm{Ma}$ ago to about $11 \mathrm{~cm} /$ year some $18 \mathrm{Ma}$ ago. The slip rate parallel to the margin remained low, varying from about 2 to $4 \mathrm{~cm} /$ year during this entire period (personal communication, S.C. Cande, 1988).
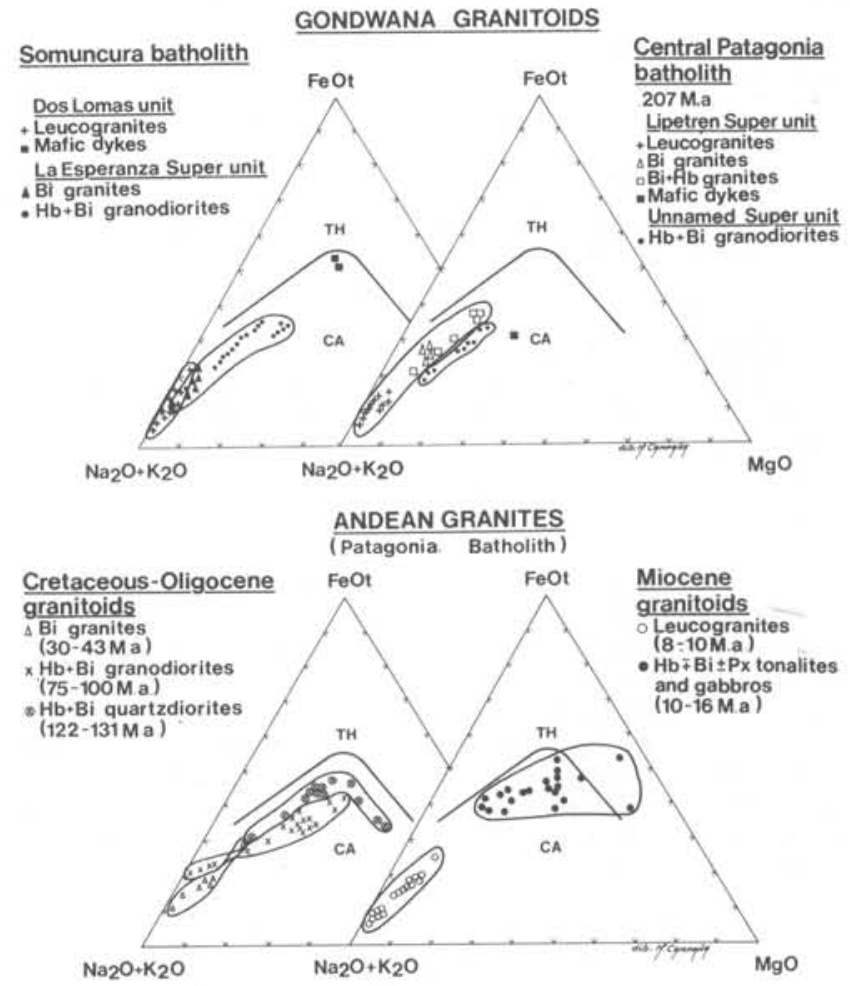

Figure 6: AFM diagrams for Gondwana and Andean granitoids, showing the boundary between the calc-alkaline (CA) and tholeitic (TH) fields. 
Several other magmatic features change with this midTertiary increase in the subduction rate along the western continental margin. For example, the younger sequences of the El Maiten Belt, which erupted at roughly the same time as this increase show mild tholeiitic and alkalic trends. Kay and Rapela (1987) conclude that the mantle source of these lavas as well as that of the older Pilcaniyeu lavas had a smaller are component than the young frontal Andean are magmas (Fig. 7). Another difference is that widespread ignimbritic and rhyolitic eruptions occurred along the Pilcaniyeu belt during the early Tertiary (Figs. 1, 5), whereas silicic rocks are rare in the Pliocene to Recent volcanic arc and back-are rocks of northern Patagonia.

In the Andean Patagonia batholith, the period of change from slow to fast convergence coincides with a minimum of plutonic activity (Fig. 3). Furthermore, during the period of slow convergence, plutonism was less voluminous than during the Cretaceous or the Neogene. Chemical differences also occurred, for the early Tertiary (43-30 Ma) Pireco granitoids (G4 in Fig. 3), emplaced during the period of slow convergence, are mainly monzon-granites and alkali-feldspar granites, whereas the 16-10 Ma Reloncavi granitoids (G5 in Fig. 3), emplaced during fast convergence, are more basic and closely resemble the compositions of the Neogene stratovolcanoes (Parada et al., in ISGAM, 1987).

Carboniferous, important volcanic and plutonic magmatic activity took place in the Somuncura batholith. This batholith and its coeval high-K volcanic suite shows calc-alkaline affinities (Figs, 6, 7) that suggest an important role for a crustal component consistent with emplacement in older continental crust. These suites contrast with the contemporaneous late Paleozoic fore-arc basins and subduction complexes with abundant mafic rocks that occur along the southwest Patagonian continental margin (Uliana et al., 1985 , and see article by Hervé in this issue).

Explanation of these magmatic events requires an understanding of Paleozoic events in reconstructed Gondwanaland, particularly in South Africa. Several explanations have been advanced, the first of which suggests that these Gondwana magmatic rocks are related to a shallow-angle subduction zone located at the southern margin of Gondwana (Lock, 1980; Gust et al., 1985). Problems with this hypothesis involve differences between style of deformation and type of magmatic rocks in this region compared to those in areas of modern shallow subduction (Ramos, 1986). Furthermore, the model of Gust and others (ibid) ignores the existence of older crust in the Malvinas plateau and southern South America (Ramos, ibid). Other workers have postulated that subduction along the paleo-Pacific margin east of the present trench can explain the magmatic activity in the Somuncura batholith (Forsythe, 1982; Uliana and Biddle, 1987, and see Fig. 2). However, the details of how such a subduction zone operated are obscure.

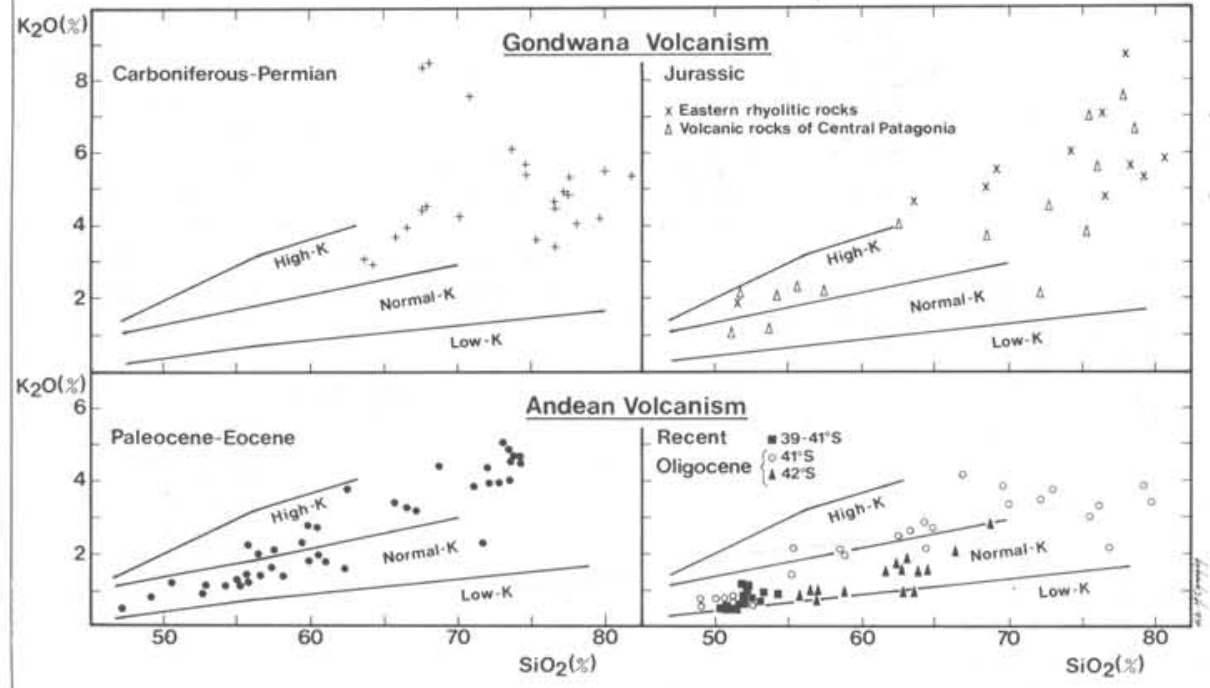

Alternatively, Ramos suggests (1984b, 1986) that the deformational and magmatic patterns are more easily understood if the early part of the Somuncura batholith were part of a continental arc related to a southwest-directed subduction zone that terminated in a late Paleozoic collision between Gondwana and a separate Patagonian continent (including the Antaretic Peninsula). This collision, along with those of the terranes in southwest Patagonia, represents the final stages of Gondwana formation. In this model, a second east-dipping subduction zone along the Pacific margin is needed to explain the distribution of Paleozoic plutonic rocks here (V. Ramos, personal communication, 1988). Although possible, a definable suture and other features

Figure 7: Plot of $\mathrm{K}_{2} \mathrm{O}$ versus $\mathrm{SiO}_{2}$ with age distance from the modern trench. Data from Rapela and others, (1988; in Ramos, 1984a), Llambias and others (in Ramos, 1984a), Uliana and co-workers (1985), and Hickey and others (1986).

These observations suggest that near the end of the period of slow convergence both are and back-are regions were characterized by a relative lack of compression. More extensive melting in the mantle in the near and far back-are region is suggested by the chemistry of the Oligocene to Early Miocene lavas (Kay and Rapela, 1987). The Miocene Reloncavi granitoids in the Andean Patagonia batholith in Chile and the younger Andean basaltic stratovolcanoes represent the products of the new normal subduction regime, that is still active today.

\section{Magmatism and the Evolution of Gondwana}

$\mathrm{K}-\mathrm{Ar}$ ages between 340 and $380 \mathrm{Ma}$ from widely spaced plutonic localities (Toubes and Spikermann, 1973; Lizuain, 1981; Rapela et al., 1987; Linares et al., 1988) in northern Patagonia suggest that plutonic activity started in this region in the Late Devonian (Fig. 2). During the Early associated with a subduction zone have not yet been recognized in the Somuncura region. The siliceous character of the Somuncura batholith is also not typical of subductionrelated plutonism.

Another possible alternative is shown in Figure 2a. Here the Late Devonian to Early Carboniferous rocks of the Somuncura batholith and plutonic rocks of similar age to the north in the Sierras Pampeanas (Rapela et al., 1988) are considered to be an inner Cordilleran are behind a magmatic are represented by plutonic rocks in the Andean Cordillera. The Sierras Pampeanas rocks are more alkaline than those in Patagonia but may have formed over older thicker crust. This model requires important NW-SE directed shearing and faulting during the late Paleozoic to explain the deformation in the Ventana fold belt (Fig. 1, and Martinez, 1986). Crustal melting accompanied this deformational period.

The Jurassic Central Patagonia batholith also appears to occur in a shear zone related to northwest faulting. These silicic magmas may represent crustal melts resulting from associated basaltic intrusions at depth. The location of the Central Patagonia batholith in this region correlates with a principle zone of shearing and graben formation (Uliana and Biddle, 1987). 


\section{The Problem of the Silicic Rocks}

Another important problem in Gondwana magmatic history is the origin of the widespread sequences of silicic voleanic rocks and related granites, particularly the Permo-Triassic Choiyoi Group (Fig. 2, and on Fig. 1 the Lihuel Calel plateau) and the Jurassic Chon Aike Group (the Marifil volcanics on Fig. 1). In northern Patagonia, northwesttrending grabens and half-grabens associated with continental extension roughly parallel the axes of the Somuncura and Central Patagonia batholits and appear to be related to the silicic volcanism (Gust et al., 1985).

Gondwana rhyolitic volcanism is not restricted to northern Patagonia, for widespread Permo-Triassic rhyolites (Choiyoi Formation) and related granites north of $39^{\circ} \mathrm{S}$ show many features in common with the Somuncura magmatism (Rapela and Llambias, 1985). Likewise, silicic Jurassic volcanism extends throughout most of Patagonia (Gust et al., ibid).

Some understanding of these magmatic events may be reached by analogy with the Cenozoic history of northern Patagonia and from recent work on Gondwana magmatism by S.M. Kay, V. Ramos, M. Mpodozis and P. Sruoga. Likewise, Gondwana silicic magmatism was contemporaneous with a period of minimal subduction along much of the modern South American margin (Fig. 2). During this time, widespread accumulation of basaltic magmas at the base of the lower crust, produced perhaps by thermal blanketing of a super-continent (Gurnis, 1988), resulted in extensive melting. Unlike the Cenozoic basalts, the Gondwana mafic magmas in the main intruded the relatively new (Paleozoic) accreted crust that had not been depleted in low melting components. Subsequent melting of this undepleted crust led to the production of the extensive Gondwana silicic magmas, which were either erupted or ponded in the middle to upper crust to form a ductile eap trapping the basaltic magmas below.

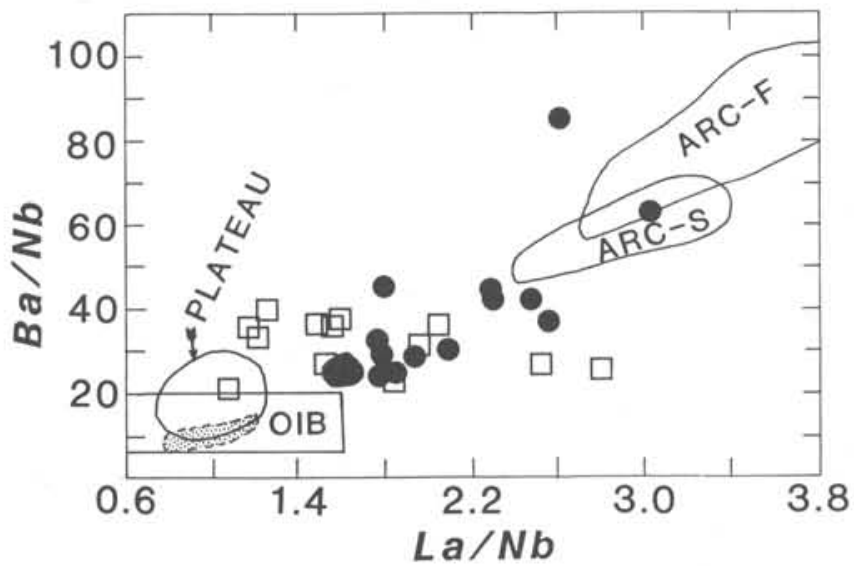

Figure 8: $\mathrm{Ba} / \mathrm{Nb}$ and $\mathrm{La} / \mathrm{Nb}$ ratios in Tertiary to Recent volcanic rocks of northern Patagonia $\left(40^{\circ}\right.$ to $\left.43^{\circ} \mathrm{S}\right)$. Patterned region in ocean island basalt box (OIB) is for samples of plateau basalts from $45^{\circ}-47^{\circ} \mathrm{S}$ (data from Hawkesworth, 1979). Circled field labelled "Plateau" includes unpublished data from plateau basalts. $A R C-F$ and $A R C-S$ are fields for frontal and secondary volcanoes in the Pliocene to Recent arc (data from Hickey et al., 1986, and in press). Samples from the Pilcaniyeu-El Maiten belts indicated by open squares (Oligocene) and solid circles (pre-oligocene).
Summary

The breakup of Gondwana and the opening of the South Atlantic during the Late Jurassic-Early Cretaceous were related in time to a westward shift in the axis of magmatism from the Central Patagonia batholith to the Andean belt closer to the Pacific margin (Fig. 2). Extensive midJurassic silicic volcanism was followed by the opening of a marginal basin to the south in the western Pacific margin, and subsequently by the emplacement of the Andean Patagonia batholith (Dalziel, 1981; Dalziel et al., 1987).

The age of the oldest oceanic lithosphere in the South Atlantic (130 $\mathrm{Ma}$ according to Rabinowitz and La Brecque, 1979 ) is about the same as the early main unit of the Andean Patagonia batholith. Major tectonic re-arrangement occurred in the South Atlantic Mid-Late Jurassic, associated with the subduction of the proto-Pacific oceanic lithosphere and intimately linked to the fragmentation of Gondwana (Dalziel et al., 1987).

The ultimate origin of the Patagonian Gondwana magmatic belts is still a matter of speculation. In simple terms, the history of northern Patagonia can be explained in terms of an earlier Paleozoic subduction regime, followed by a late Paleozoic to early Mesozoic phase in which extensive crustal melting was associated with a period of relaxation and extension. Renewed subduction during the late Mesozoic and Cenozoic accounts for more recent events.

\section{Acknowledgements}

This work was supported by CONICET (Argentina) grants $39045-01 / 03$, and is a contribution to IGCP Project 249 "Andean Magmatism and its Tectonic Setting." We wish to especially thank Victor Ramos for discussions that improved the content of this paper. L. Spalletti, R.W. Kay, L. Dalla Salda and C. Cingolani also provided valuable comments.

Dr. C. W. Rapela is Professor of Geochemistry at La Plata University (Centro de Investigación Geológicas, Universidad de La Plata, Calle 1 No. 644, 1900 La Plata, Argentina). He works on the igneous petrology and geochemistry of magmatic ares of southern South America, with special emphasis on Patagonian Andean and extra-Andean magmatism. He is joint leader of IGCP Project 249.

Dr. S. M. Kay is a Senior Research Associate in the Institute for the Study of the Continents at Cornell University (Snee Hall, Ithaca, N.Y. 14853-1504, U.S.A.). She works on the geochemical and petrologic characteristics of igneous rocks with regional tectonics in the Aleutian Arc, and in the Argentine and Chilean Andes. She is regional vice-president of IGCP Project 249.
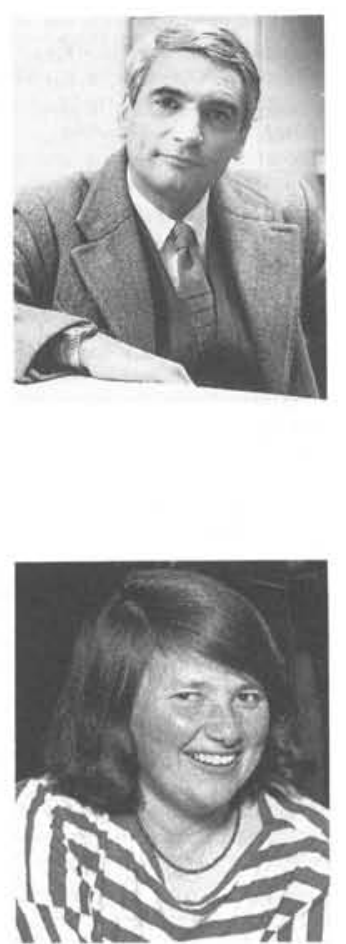


\section{References}

Alonso, G.B., 1987. Resultados geoguímicos y geocronológicos preliminares de los cuerpos graníticos de Pilcaniyeu, provincia de Rio Negro. In: Rapela, C.W. (ed.), Symposium on Cireum-Pacific Phanerozoic Granites. Actas del $\mathrm{X}$ Congreso Geológico Argentino, Asociación Geológica Argentina, v. 4, p. $27-29$.

Caminos, R. and Parica, C., 1985. The significance of new $\mathrm{Rb} \mathrm{b}-\mathrm{Sr}$ ages of igneous rocks from northern Patagonia. Departamento de Geología, Universidad de Chile Comunicaciones, v. 35, p. 41-43.

Cande, S.C. and Leslic, R.B., 1986. Late Cenozoie tectonies in the southern Chile Trench. Journal of Geophysical Research, v. 9l, p. 47I-496.

Cobbing, E.J. and Pitcher, W.S., 1972. The coastal batholith of Peru. Journal of the Geological Society of London, v. 128, no. 5, p. 42J-460.

Coira, B., Franchi, V. and Nullo, F., 1985. Vulcanismo Terciario al oeste de Somuncura y su relación con el areo magmático de la Cordillera Norpatagonica, Argentina. Actas IV Congreso Cieologico Chileno, Antofagasta, v. 4, no. 3 , p. $4-68$.

Corbella, II., 1975. Hallazgo de un complejo alcalino vinculado a megatrazas de fracturas corticales en la Sierra de Quepuniyeu, Macizo Norpatagonico, provincia de Rio Negro, Argentina. Il Congreso Ibero Americano de Geología Económica, v. IV, p. 45-68.

Cortes, J.M., I981. El substrato precretacico del extremo noreste de la provincia del Chubut. Revista Asociación Geológica Argentina, v. 36, no. 3, p. $218-235$,

Dalla Salda, L. and Franzese, J., 1987. Las megaestructuras del Macizo y Cordillera Norpatagonica Argentina y la genesis de las cuencas volcanosedimentarias terciarias. Revista Geológica de Chile, v. 31, p. 3-13.

Dalziel, 1.W.D, 1981. Back-are extension in the southern Andes: a review and critical reappraisal. Philosophical Transactions of the Royal Society of London, v. A300, no. 1454 , p. 319-35.

Dalziel, I.W.D., Storey, B.C., Garrett, S.w., Grunow, A.M., Herrod, L.D.B. and Pankhurst, R.F., 1987. Extensional tectonics and the fragmentation of Condwanaland. In: Coward, M.P., Dewey, J.F. and Ilancock, P.L. (eds.), Continental Extensional Tectonics. Geological Socicty Special Publication 28, p. 433-441.

Forsythe, R., 1982. The late Palaeozoic to carly Mesozoic evolution of southern South America: a plate tectonic interpretation. Journal Geological Society of London, v. 139, no. 6, p. 671-82.

González Diaz, E.F., 1982. Chronological zonation of granitic plutonism in the northern Patagonian Andes of Argentina: the migration of intrusive eycles. Earth Seience Reviews, v. 18, no. 3-4, p. 365-393.

Gurnis, M., 1988. Large-seale mantle convention and the aggregation and dispersal of supercontinents. Nature, v. 332, p. 695-699.

Gust, 1).A., Biddle, K.T., Phelps, D.W. and Uliana, M.A., 1985. Associated Middle to Late Jurassic volcanism and extension in southern South America. T'ectonophysics, v. 116 , no. $3-4$, p. 223-53.

Harmon, R.S. and Barreiro, B.A. (eds.), 1984. Andean Magmatism. Shiva Publishing, Cheshire, U.K., 340 p.

Hawkesworth, C.J., Norry, M.d., Roddick, J.C. and Baker, P.E., 1979. $143 \mathrm{Nd} /{ }^{44} \mathrm{Nd}, 87_{\mathrm{Sr}} / 86 \mathrm{Sr}$, and incompatible element variations in calc-alkaline andesites and plateau lavas from South America. Earth and Planetary Science Letters, v. 42, no. l, p. 45-47.

Hickey, R.L., Frey, F.A. and Gerlach, D.C., 1986. Multiple sources for basaltic are rocks from the Southern Volcanic zone of the Andes $\left(34^{\circ}-41^{\circ} \mathrm{S}\right)$ : Trace element and isotope evidence for contributions from subducted oceanic crust, mantle and continental crust. Journal of Geophysical Research, v. 91, no. 6, p. 5963-5983.

Hickey-Vargas, R., Moreno-Roa, H., Lopez-Escobar, L. and Frey, F.A., in press. Geochemical variations in Andean basaltic and silicic lavas from the Villarrica-lanin Volcanic chain $\left(39.5^{\circ} \mathrm{S}\right)$ : An evaluation of source heterogeneity, fractional crystallization and crustal assimilation. Contributions to Vineralogy and Petrology.

ISGAM, 1987. Proceedings of International Symposium on Granites and Associated Mineralizations. Revista Brasileira de (ieociências, v. 17, no. 4, p. 349-706.

Kay, S.M. and Rapela, C.W., 1987. El voleanismo del Tereiario Inferior y medio en los Andes Norpatagonicos $\left(40^{\circ}-42^{\circ} 30^{\prime}\right.$ s): Origen de los magmas y su relación con variaciones en la oblicuidad de la zona de subducción. symposium on Andean Volcanism, Actas del X Congreso Geológico Argentino, Asociación Geológica Argentina, v. 4, p. 192-194.

Linares, L., Llambias, L.J. and Lutorre, C.O., 1980. Geología de la Provineia de La Pampa, República Argentina y geocronologia de sus rocas metamórficas y eruptivas. Revista Asociación Geológica Argentina, v. 35, p. 87-146.

Linares, E., Cagnoni, M.C., 10 Campo, M. and Ostera, 11.A., 1988. Geochronology of metamorphic and eruptive rocks of southeastern Neuquén and northwestern Rio Negro provinces, Argentine Republic. Journal of South American Earth Sciences, v. l, no. 1, p. 53-61.

Lizuain, A., 1981. Características y edad del plutonismo en los alrededores del Lago Puelo, Provincia del Chubut. Actos del VIII Congreso Geológico Argentino, v. 3, p. 607-616.

Llambias, E.J. and Rapela, C.W., 1984. Geología de los complejos eruptivas de La Esperanza, provincia de Rio Negro, Revista Asociación Geológica Argentina, 39, p. 220-243.
Llambias, E.J., Rapela, C.W. and Parica, C., 1985. Rb-Sr Grochronology of La Esperanza eruptive complexes, North Patagonian Nassif $\left(68^{\circ} 28^{\prime} \mathrm{W}\right.$, $\left.40^{\circ} 29^{\prime} \mathrm{S}\right)$. Departamento de Geología, Universidad de Chile, Comunicaciones, v. 35 , p. 149-153.

Lock, B.E., 1980. Flat-plate subduction and the Cape fold belt of South Africa. Geology, v. 8, no. 1, p. 35-39.

Marshall, L.G., Pascual, R., Curtis, G.H. and Drake, R.t., 1977. South American geochronology: Radiometric time scale for middle to late Tertiary mammal-bearing horizons in Patagonia. Science, v. 195, no. 4284, p. $1325-1328$.

Martinez, J.S., 1986. Las Sierras australes de Buenos Aires: Su vinculación a un cizallamiento regional. Revista Asociación Geológica Argentina, v. 41 no. $1-2$, p. $187-190$

Munizagd, F., Herve, F., Drake, R., Pankhurst, R., Brook, M. and Snelling, $V$ in press. Geochronology of the granitoids of the Andean lake region $\left(39^{\circ}-42^{\circ} \mathrm{S}\right.$ Lat) south-central Chile, preliminary results. Journal of South American Earth Sciences, v. 1.

Musacchio, E.A. 1981. Estratigrafia de la Sierra Pampat de Agnia en la region extra-Andina de la provincia de Chubut, Argentina. Actas del VIII Congreso Geológico Argentino, v. 3, p. 343-357.

Page, S.M.N. and Page, R.F.N., 1987. H1 Jurásico Volcánico de la recrion Gastre-Pire Mahuida, provincia del Chubut. Symposium on Andean Voleanism, Actas del $x$ Congreso Geológica Argentino, Asociación Geológica Argentina, v. 4 , p. 174-176.

Rabinowitz, P.D, and La Brecque, J.L., 1979. The Mesozoic South Atlantic Ocean and evolution of its continental margins. Journal of Geophysical Research, v. 84, no. B11, p. 5973-6002.

Ramos, V., (ed.), 1984a, Geología y Recursos Naturales de la Provincia de Rio Negro. Relatorio IX Congreso Geológico Argentina, Asociación Ceológica Argentina, $784 \mathrm{p}$.

Ramos, V.A., 1984b. Patagonia: Un continente Paleozoico a la deriva? Actas del IX Congreso Geológico Argentino, v. 2, p. 311- 325 .

Ramos, V.A., 1986. Discussion of "Tectonostratigraphy, as applied to analysis of South African Phanerozoic basins" by II. de La R. Winter. Transactions of the Geological Society of South Africa, v. 89, no. 3, p. 427-429.

Ramos, V.A., Niemeyer, H., Skarmeta, J. and Munoz, J., 1982. The magmatic evolution of the Austral Patagonian Andes. Earth Science Reviews, v. 18, no. 3-4, p. 411-443.

Rapela, C.W., 1987. Geochemical characteristics and tectonic setting of the northern Patagonian Batholith $\left(40^{\circ}-42^{\circ} \mathrm{S}\right)$. EOS, Transactions American Geophysical Union, v. 68, no. 44, p. 1527.

Rapela, C.W., Harrison, S.M. and Pankhurst, R.J., in press. Latest Gondwanaland plutonism in central Patagonia: Granitoids in the Gastre Area $\left(42^{\circ} 15^{\prime}, 69^{\circ} 13^{\prime}\right)$. Geological Society of America Abstracts with Program.

Rapela, C.W. and Llambias, E.J., 1985. Evolución magmática y relaciones regionales de los complejos eruptivas de La Esperanza, Provincia de Rio Negro. Revista de la Asociación Geológica Argentina, v. 40, no. 1-2, p. $4-25$.

Rapela, C.W., Munizaga, F., Dalla Salda, L., Herve, F., Parada, M.A. and Cingolani, C., 1987. Nuevas edades $\mathrm{K} / \mathrm{Ar}$ de los granitoides del sector nororiental de los Andes Patagonicos. In: Rapela, C. (ed.), Symposium on Circum-Pacific Phanerozoic Granites. Actas de X Congreso Geológico Argentino, Asociación Geológicas Argentina, v. 4, p. 18-20.

Rapela, C.W., Spalletti, L.A. and Merodio, J.C., 1983. Evolución magmática y geotectónica de la "Serie Andesitica" andina (Paleoceno-Eoceno) en la Cordillera Norpatagonica. Revista Asociación Geológica Argentina, v. 38 no. $3-4$, p. $469-484$

Rapela, C.W., Spalletti, L.A., Merodio, J.C. and Aragon, E., 1988. Temporal evolution and spatial variation of parly Tertiary volcanism in the Patagonian evolution and spatial variation of carly Tertiary volcanism in the Patagonian p. $75-88$.

Stipanicic, P.N., Toubes, R.O., Spikermann, J.P. and Halpern, M., 1971. Sobre la composición y edad de algunas plutonitas del nordeste de la provincia de Santa Cruz, Patagonia (Rep. Argentina). Revista Asociación Geológica Argentina, v. 26, p. 459-467.

Toubes, R.O. and Spikermann, J.P., 1973. Algunas edades K-Ar y Rb-Sr de plutonitas de la Cordillera Patagonica entre los paralelos 40 y 44 de latitud sur. Revista Asociación Geológica Argentina, v. 28, no. 4, p. 382-396.

T'urner, J.C.M. and Baldis, B.A.J., 1979. La estructura transeontinental del limite septentrional de la Patagonia. Actas del VII Congreso Geológico Argentino, v. 2, p. 225-238.

Uliana, M.A., Biddle, K.T., Phelps, D.W. and Gust, D.A., 1985. Significado del volcanismo y extension mesojurásicas en el extremeo meridional de Sudamerica. Revista Asociación Geológica Argentina, v. 40, no. 3-4, p. 231-253.

Uliana, M.A. and Biddle, K.I'., 1987. Permian to late Cenozoic evolution of northern Patagonia, main tectonic events, magmatic activity, and depositiona' trends. In: McKenzie, G.D. (ed.), Gondwana Six: Structure, Tectonics, and Geophysics, AGU Geophysical Monograph 40, p. 271-286. Weaver, S.G., Bruce, R., Nelson, E.P., Brueckner, II.K. and Lehuray, A.P., in press. $\mathrm{Sr}, \mathrm{Nd}$ and $\mathrm{Pb}$ isotope variations in the Patagonia batholith, $48^{\circ} \mathrm{S}$ latitude, Chile: implications for the evolution of crustal contributions. Plutonism from Antaretica to Alaska. Geological Society of America Memoir. 